\title{
Properties of Phytotoxic Cell-wall Components of Plant Pathogenic Pseudomonads
}

\author{
By R. C. HIGNETT AND A. V. QUIRK* \\ East Malling Research Station, Maidstone, Kent ME19 6BJ
}

(Received 5 May 1978)

\begin{abstract}
A phytotoxic extract of Pseudomonas morsprunorum (cherry isolate c28) was shown to contain phytotoxic protein associated with bacteriophage-specific lipopolysaccharide. This and similar extracts from two other pathogenic pseudomonads produced a silvery effect when infiltrated at $100 \mu \mathrm{g} \mathrm{ml}^{-1}\left(14.4 \mu \mathrm{g}\right.$ protein $\left.\mathrm{ml}^{-1}\right)$ into leaves of some plant species. The effect was similar to that caused by Stereum purpureum infection in cherry. In contrast to the fungal toxin, the bacterial extracts were not translocated in treated plants. Waxembedded sections of cherry leaves silvered either by the fungus or by bacterial extracts showed optically active cells when stained with toluidine blue. Different plant species differentiated between extracts of different pseudomonads by their reaction to treatment. The hypersensitive response of tobacco to heterologous pathogenic bacteria was suppressed by prior treatment with extracts of cherry-type and saprophytic bacteria. Similar phytotoxic material isolated from culture filtrates of the cherry isolate produced the silvery effect in bean leaves when infiltrated at $10 \mu \mathrm{g} \mathrm{ml}^{-1}\left(5 \mu \mathrm{g}\right.$ protein $\left.\mathrm{ml}^{-1}\right)$. The silvering agents (molecular weight in excess of $25 \times 10^{6}$ by gel filtration) were dissociated into smaller units by electrophoresis in sodium dodecyl sulphate-polyacrylamide gel. The activities described were destroyed by protein-inactivating treatments.
\end{abstract}

\section{INTRODUCTION}

During work on bacteriophage receptor-site material extracted from Pseudomonas morsprunorum, it was observed that protein was associated with the phage-specific lipopolysaccharide. A brief report on the phytotoxicity of the protein complex has been published (Hignett \& Quirk, 1975). Sensitivity to phage is associated with the virulence of the pathogen, a decline in virulence always being accompanied by loss of sensitivity (Garrett et al., 1974). However, the purified lipopolysaccharide (LPS) which constitutes the phage-specific receptor apparently had no direct role in pathogenicity (Quirk et al., 1976). To determine the nature of the relationship between virulence and sensitivity to phage, further work on the LPS-protein complex was done using a wider range of bacteria and plants.

\section{METHODS}

The saprophyte Pseudomonas fluorescens (P65), the plant pathogenic bacteria Pseudomonas phaseolicola (F3) and Pseudomonas morsprunorum (cherry isolate C28 and plum isolate D10) were grown at 20 to $25^{\circ} \mathrm{C}$ on nutrient glycerol agar $[0.8 \%(\mathrm{w} / \mathrm{v})$ nutrient broth (Difco), $1.5 \%(\mathrm{v} / \mathrm{v})$ glycerol and $2 \%(\mathrm{w} / \mathrm{v})$ agar (Oxoid)] and stored at $4{ }^{\circ} \mathrm{C}$. The hypersensitive response test, specific for plant pathogens, was routinely applied using tobacco (Klement, 1963). Cultures were tested for purity by the Gram-stain method and by growth on nutrient sucrose agar (NSA; Crosse, 1959).

Cultures were originally grown in broth by the methods described by Quirk et al. (1976). Later, the basal medium of Erikson (1945) was used. This was modified to contain $0.7 \%(\mathrm{w} / \mathrm{v})$ glucose, $0.45 \%(\mathrm{w} / \mathrm{v})$

* Present address: Department of Biochemistry, University of Newcastle upon Tyne. 
$\mathrm{NaNH}_{4} \mathrm{HPO}_{4} \cdot 4 \mathrm{H}_{2} \mathrm{O}, 0.17 \%(\mathrm{w} / \mathrm{v}) \mathrm{KH}_{2} \mathrm{PO}_{4}, 0.01 \%(\mathrm{w} / \mathrm{v}) \mathrm{MgSO}_{4} .7 \mathrm{H}_{2} \mathrm{O}$ and $1 \mathrm{ml} 1^{-1}$ of trace elements (Bauchop \& Elsden, 1960). The modifications reduced the generation time from 3.5 to $2.5 \mathrm{~h}$, the exponential phase ending at about $10^{9}$ cells $\mathrm{ml}^{-1}$.

Cells were harvested at the end of the exponential phase by centrifugation $\left(0^{\circ} \mathrm{C}, 5000 \mathrm{~g}, 20 \mathrm{~min}\right)$ and washed by resuspension in water. They were recentrifuged and resuspended in 5 vol. $1 \%(\mathrm{w} / \mathrm{v})$ $\mathrm{Na}_{2}$ EDTA. $2 \mathrm{H}_{2} \mathrm{O}$ adjusted to $\mathrm{pH} 6$ with $2 \mathrm{M}-\mathrm{NaOH}$. After incubation at $0{ }^{\circ} \mathrm{C}$ for $1 \mathrm{~h}$, the suspension was centrifuged $\left(0^{\circ} \mathrm{C}, 40000 \mathrm{~g}, 20 \mathrm{~min}\right)$ and the supernatant was filter-sterilized $(0.45 \mu \mathrm{m}$ pore-size membrane, Millipore). The extract was washed five times at $0{ }^{\circ} \mathrm{C}$ with 1 vol. ether and the aqueous phase was dialysed against five changes of water at $0^{\circ} \mathrm{C}$ over a period of 2 to $3 \mathrm{~d}$. The retained material was concentrated under vacuum at $35^{\circ} \mathrm{C}$ to about $1 \mathrm{mg} \mathrm{ml}^{-1}$, and freed from nucleic acid by electrophoresis in an agarose block (Quirk et al., 1976).

The culture filtrate was similarly sterilized and washed with ether. The aqueous phase was concentrated under vacuum to $0 \cdot 1 \mathrm{vol}$, then dialysed against three changes of water at $0{ }^{\circ} \mathrm{C}$ over a period of 2 to $3 \mathrm{~d}$ and finally concentrated to about $1 \mathrm{mg} \mathrm{ml}^{-1}$. In later experiments the dialysis step was replaced in all preparations by direct fractionation on Sepharose $2 \mathrm{~B}$, the excluded fraction being retained. Partially degraded material from broth cultures was fractionated on Sephadex G-100 columns $(1.8 \times 46 \mathrm{~cm})$, equilibrated in water or $0.1 \mathrm{~m}$-sodium phosphate ( $\mathrm{pH} \mathrm{7)}$. The fractions, eluted at $0.3 \mathrm{ml} \mathrm{min}-1$, were monitored at $275 \mathrm{~nm}$. Protein was estimated by the method of Lowry et al. (1951), using crystalline bovine serum albumin (BDH) standards. Extracts in 0.01 M-phosphate ( $\mathrm{pH} 7$ ) were digested with Pronase (Grade B, Calbiochem) at $37^{\circ} \mathrm{C}$ for $1 \mathrm{~h}$.

Electrophoresis in sodium dodecyl sulphate-polyacrylamide gel (SDS-PAGE) was carried out using 5\% $(\mathrm{w} / \mathrm{v})$ Cyanogum $41(\mathrm{BDH})$ made up in $0.1 \mathrm{M}-\mathrm{Tris}(\mathrm{BDH})$, adjusted to $\mathrm{pH} 8.9$ with $6 \mathrm{M}-\mathrm{HCl}$, containing $0.1 \%(\mathrm{w} / \mathrm{v})$ SDS. The gel was polymerized with $0.2 \%(\mathrm{w} / \mathrm{v})$ ammonium persulphate and $0 \cdot 2 \%(\mathrm{v} / \mathrm{v})$ 2-dimethylaminoethyl cyanide (BDH). The same Tris/SDS buffer was used in the electrode compartments. Samples were solubilized in $1 \%(\mathrm{w} / \mathrm{v}) \mathrm{SDS}$ at $37^{\circ} \mathrm{C}$ for $1 \mathrm{~h}$ before electrophoresis. Gels were run at $5 \mathrm{~mA}$ per rod, using bromophenol blue (in a separate rod) as a tracker dye. After fixation in $10 \%$ (w/v) trichloroacetic acid at room temperature for $2 \mathrm{~h}$, the gels were rinsed with water and stained with $0 \cdot 25 \%(\mathrm{w} / \mathrm{v})$ Coomassie Brilliant Blue R (R. A. Lamb, Wembley) in methyl alcohol/acetic acid/water (20:7:73, by vol.) for $2 \mathrm{~h}$; excess stain was removed with the same solvent. Carbohydrate was detected by the periodateSchiff reaction; gels were immersed in $0.8 \%(\mathrm{w} / \mathrm{v})$ periodic acid in $2 \%(\mathrm{v} / \mathrm{v})$ aqueous pyridine for $30 \mathrm{~min}$, washed with water for $30 \mathrm{~min}$ and then treated with decolourized Schiff reagent.

Toxicity of extracts was tested by infiltrating seedling leaves under vacuum (Hignett, 1975) or by syringe (Klement, 1963). The following species were used: Prunus avium (Bigarreau Moreau), Prunus cerasifera (Myrobalan), Phaseolus vulgaris (Canadian Wonder) and Nicotiana tabacum (White Burley).

Leaf material was embedded in wax after dehydration in a water/ethyl alcohol/tert-butyl alcohol series. Sections $(12 \mu \mathrm{m})$ were stained with $0.05 \%(\mathrm{w} / \mathrm{v})$ aqueous toluidine blue before being dewaxed in xylene.

\section{RESULTS AND DISCUSSION}

Infiltration of leaves with extracts of plant pathogenic bacteria caused a silvery effect in three species of test plant within a few days of treatment. Figure 1 shows the effect of an EDTA extract of cherry-type bacteria on cherry leaves. The sharply delineated regions corresponded exactly with the areas waterlogged during infiltration. Silvering was not produced by injection of extracts into the petioles, or by standing freshly detached leaves in the extracts. The absence of translocation thus demonstrated contrasts with the freely mobile silver-leaf disease toxin produced by the fungus Stereum purpureum (Brooks \& Brenchley, 1931). The silvery effect produced by the latter was very similar to that described above.

The small air gap visible in sections of cherry leaves affected by $S$. purpureum (arrowed in Fig. $2 a$ ) was not visible in cherry leaf sections silvered by bacterial extracts (Fig. $2 b$ ) and was not detected in sections examined in the electron microscope. However, the silvery effect disappeared from leaves affected by the fungus or by the bacterial products after vacuum infiltration with water. The effect reappeared when the leaves were allowed to dry out. In addition, the upper epidermal layer of silvered bean leaves could be stripped off (with finepointed forceps) only in the silvered areas, suggesting a weakness in the intercellular adhesion, and indicating that a small air gap may be present. The epidermal stripping test could not be applied to the other two species tested (cherry and Myrobalan cherry-plum) because of the nature of their leaves. 


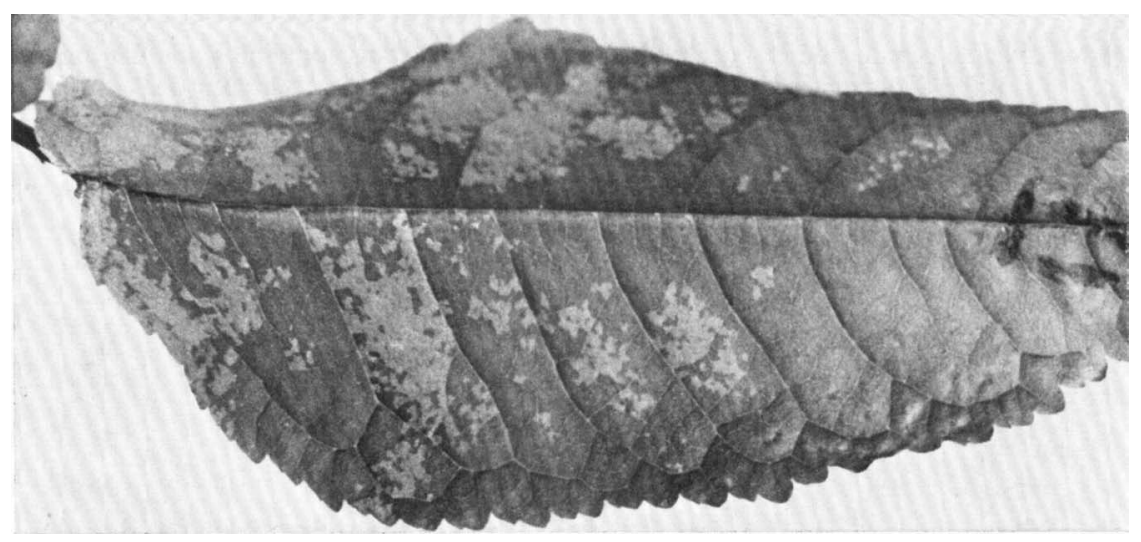

Fig. 1. Silvery effect produced on cherry leaf after infiltration with an EDTA extract of cherry-type bacteria.
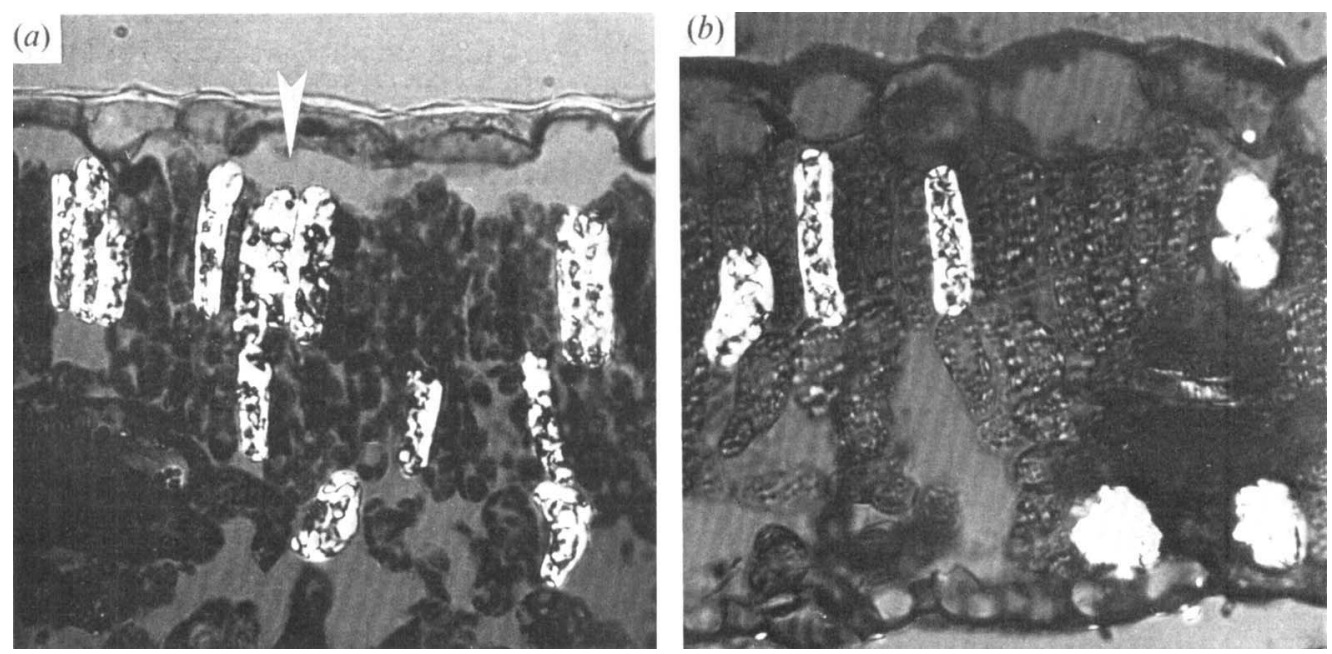

Fig. 2. Stained sections of cherry leaf: (a) affected by Stereum purpureum (arrow indicates air gap); (b) silvered by bacterial extract. Both photographed by polarized light.

Optical activity was seen in stained sections of cherry leaves silvered by treatment with the bacterial extracts, or affected by $S$. purpureum (Fig. $2 a, b$ ), but not in untreated healthy leaves. The optically active cells in these sections were not distinguishable under nonpolarized light and were not observed when basic stains other than toluidine blue were used. We do not know the nature of the reaction with toluidine blue. The affected cells seemed to be normal in all other respects, and survived as well as other leaf cells in the intact plant. Table 1 shows that cherry leaves exhibited both the silvering and optical effects after treatment with extracts $\left(1 \mathrm{mg} \mathrm{ml}^{-1}\right)$ of all three pathogens, but the Myrobalan cherry-plum leaves were unaffected by extracts of the plum isolate. The bean leaves gave only the silvering reaction. Although tobacco was apparently unaffected, injected areas of leaf failed to show the hypersensitive response (HR) when subsequently inoculated with the pathogenic pseudomonads. Thus the extracts of different pathogenic bacteria were differentiated to some extent by the test plants. Extracts were also effective at $100 \mu \mathrm{g} \mathrm{ml}^{-1}$ $\left(14.4 \mu \mathrm{g}\right.$ protein $\left.\mathrm{ml}^{-1}\right)$. None of the plants showed either silvering or optical activity after 


\section{Table 1. Effects of bacterial extracts on plants}

Leaves were vacuum-infiltrated or injected (tobacco) with solutions containing about $1 \mathrm{mg}$ extract $\mathrm{ml}^{-1}$, and examined for silvering activity (S) and optical activity (O).

\begin{tabular}{|c|c|c|c|c|c|c|c|c|}
\hline \multirow[b]{3}{*}{ Bacterial extract } & \multicolumn{8}{|c|}{ Test plants } \\
\hline & \multicolumn{2}{|c|}{ Cherry } & \multicolumn{2}{|c|}{ Myrobalan } & \multicolumn{2}{|c|}{ Bean } & \multicolumn{2}{|c|}{ Tobacco } \\
\hline & $\mathbf{S}$ & $\mathrm{O}$ & $\mathrm{S}$ & $\mathrm{O}$ & $\mathbf{S}$ & $\mathrm{O}$ & S & $\mathrm{O}$ \\
\hline c28 (cherry) & + & + & + & + & + & - & - & - \\
\hline D10 (plum) & + & + & - & - & + & - & - & - \\
\hline F3 (bean) & + & + & + & + & + & - & - & 一 \\
\hline P65 (saprophyte) & - & - & - & - & - & $\mathrm{NT}$ & - & - \\
\hline
\end{tabular}

infiltration with extracts of the saprophyte, but tobacco plants were protected against $\mathrm{HR}$ as before.

Material isolated from culture filtrates of the cherry isolate also caused silvering when infiltrated at $10 \mu \mathrm{g} \mathrm{ml}^{-1}\left(5 \mu \mathrm{g}\right.$ protein $\left.\mathrm{ml}^{-1}\right)$ into cherry or bean leaves. The optical activity described before was not observed, although the anti-HR activity was detected in tests on tobacco. The molecular weight of material from culture fluid (in excess of $25 \times 10^{6}$ by gel filtration) was similar to that of the EDTA extracts. Both substances were excluded from polyacrylamide gel in the absence of SDS during electrophoresis. In the presence of SDS, both materials showed a single fast-running carbohydrate-protein band. The protein content of the EDTA extract and extracellular materials was $14.4 \%$ and $50 \%$, respectively.

Culture filtrates obtained in preliminary experiments with the cherry isolate grown in complex medium contained comparatively low molecular weight material $(<100000$ by gel filtration). This caused silvering in infiltrated cherry and bean leaves, but did not cause the optical effect in cherry or the anti-HR effect in tobacco. It is thought that this material was released by autolytic degradation of cell-wall material (caused by the relatively poor growth conditions), the optical and anti-HR activities being destroyed in the process.

The silvering activity was destroyed by treatment with SDS, heat, or by digestion with Pronase. Removal of protein from EDTA extracts of the cherry isolate by phenol treatment also destroyed the activity. It is concluded that protein was the operative agent in the silvering effect.

The evidence shows that protein associated with bacteriophage-specific LPS" on or in the bacterial cell wall has phytotoxic properties. It is suggested that the protein (by reason of its phytotoxicity) may contribute towards the virulence of the pathogen. The association between the virulence of the pathogen and its sensitivity to phage, although apparently not due to direct action of the phage-receptor LPS on the host plant, may be mediated by the protein constituent of the LPS complex.

Thanks are due to Dr C. M. E. Garrett for the provision of source cultures and to Dr A. R. W. Smith for improvements in culture media. A. V. Quirk wishes to thank the ARC for a postgraduate studentship. 


\section{REFERENCES}

BAUCHOP, J. \& ElSDEN, S. R. (1960). The growth of micro-organisms in relation to their energy supply. Journal of General Microbiology 23, 457-469.

Brooks, F. T. \& Brenchley, G. G. (1931). Further injection experiments in relation to Stereum purpureum. New Phytologist 30, 128-133.

Crosse, J. E. (1959). Bacterial canker of stone fruits. IV. Investigation of a method for measuring the inoculum potential of cherry trees. Annals of Applied Biology 47, 306-317.

ERIKSON, D. (1945). Certain aspects of resistance of plurn trees to bacterial canker. I. Annals of Applied Biology 32, 44-52.

Garrett, C. M. E., Crosse, J. E. \& Sletten, A. (1974). Relations between phage sensitivity and virulence in Pseudomonas morsprunorum. Journal of General Microbiology 80, 475-483.
Hignett, R. C. (1975). Vacuum infiltration of plant leaves in situ. Laboratory Practice 24, 586.

HigneTt, R. C. \& Quirk, A. V. (1975). Phytotoxins of plant pathogenic pseudomonads. In 10th International Congress F.E.B.S., Paris, abstr. no. 1425. Paris: Société de Chimie Biologique.

KLEMENT, Z. (1963). Rapid detection of pathogenicity of phytopathogenic pseudomonads. Nature, London 199, 299-300.

Lowry, O. H., Rosebrough, N. J., Farr, A. L. \& RANDALL, R. J. (1951). Protein measurement with the Folin phenol reagent. Journal of Biological Chemistry 193, 265-275.

Quirk, A. V., Sletten, A. \& Hignett, R. C. (1976). Properties of phage-receptor lipopolysaccharide from Pseudomonas morsprunorum. Journal of General Microbiology 96, 375-381. 